\title{
Farmers' Awareness of the Effects of Climate on Growth and Yield of Potato (Solanum Tuberosum) in Jos-South Local Government Area of Plateau State, Nigeria
}

\author{
Wuyep Solomon Zitta ${ }^{1, *}$, Samuel Akintayo Akinseye ${ }^{2}$, Yakubu Pwajok Mwanja ${ }^{3}$ \\ ${ }^{1}$ Department of Geography, Plateau State University Bokkos, Nigeria and Department of Geography, Environmental Management and \\ Energy Studies, University of Johannesburg, South Africa \\ ${ }^{2}$ Department of Geography, Environmental Management and Energy Studies, University of Johannesburg, South Africa \\ ${ }^{3}$ Department of Microbiology, Plateau State University Bokkos, Nigeria and Department of Botany and Plant Biotechnology, University of \\ Johannesburg, South Africa
}

Email address:

wuyepsol@yahoo.com (S. Z. Wuyep), sammiesam31@live.co.za (S. A. Akinseye), ubukay30@yahoo.com (Y. P. Mwanja)

\section{To cite this article:}

Wuyep Solomon Zitta, Samuel Akintayo Akinseye, Yakubu Pwajok Mwanja. Farmers' Awareness of the Effects of Climate on Growth and Yield of Potato (Solanum Tuberosum) in Jos-South Local Government Area of Plateau State, Nigeria. Agriculture, Forestry and Fisheries. Vol. 4, No. 4, 2015, pp. 179-183. doi: 10.11648/j.aff.20150404.15

\begin{abstract}
This study assessed farmers' knowledge on the effect of climate on growth and yield of potato in Jos -South Plateau State. The instrument of data collection used for this study include structured questionnaire. Purposive sampling design was followed in the selection of 200 farmers. The study was undertaken in four districts of Jos- South (Du, Vwang, Kuru and Gyel). One village was selected from each district using the simple random technique to avoid bias. Primary data collected from the farmers include socio-economic characteristics such as gender, age, marital status, years of farming experience as well as relevant questions in order to assess farmers' knowledge on the effect of climate on growth and yield of potato. Descriptive techniques of data were employed such as simple percentages to describe the knowledge of the respondents. Findings indicate that farmers have good knowledge of the effect of climate on growth and yield of potato. The effect identified includes reduced yield due to excessive rainfall during tuber bulking stage. The disease by late-blight is the most important disease that reduces the yield in the study area. It reduces between $40-80 \%$ of the total yield. However, there is need for adequate knowledge of the effect of climate on potato and adaptative strategies.
\end{abstract}

Keywords: Climate, Farmers, Potato, Knowledge, Awareness, Yield

\section{Introduction}

In recent years, there has been a growing awareness that scientific knowledge alone is inadequate for solving climate crisis. Thus, the indigenous local farmers have been recognised as powerful knowledge holders on climate change and key factors for developing policy to mitigate and cope with its effects. The knowledge of the local and indigenous farmers is increasingly recognised as important source of climate knowledge and adaptation strategies (Natural Sciences, 2012). Traditional knowledge, innovations and adaptation practices embody local adaptative management to the changing environment and compliment scientific research, observations and monitoring (International indigenous People's Forum on Climate Change, 2009).

Most local communities possess traditional and local knowledge that may help them better adapt to the impact of climate. Some communities are using traditional knowledge to record their observations of climate and its impact on the environment as a result of their close relationship with land and their dependence on natural resources for their livelihoods and have long been observing and noting the impact of climate conditions (UNESCO, 2010).

Unless appropriate mitigative and adaptive measures are taken, climate change will frustrate farmers' efforts to achieve sustainable agriculture production and food security. However, developing such strategies will require information from the farmers since the ability to adapt and cope with climate change depends on the knowledge, skills, experiences and other socio-economic factors (Maharjan et al., 2011). It is against this background that this study seeks to assess farmers' awareness on the effect of climate on 
growth and yield of Potato (Solanum tuberosum) in JosSouth Local Government Area of Plateau State, Nigeria.

\section{Study Area and Methods}

This study assesses farmers' knowledge on the effect of climate on growth and yield of potato. Jos- South-Local Government Area of Plateau State Nigeria is one of the seventeen local governments in Plateau State. It is made up of four districts: Vwang, Du, Gyel, and Kuru. The local government area has its headquarters in Bukuru. It lies on latitude $8^{\circ} 43^{\circ} \mathrm{N}$ and longitude $8^{\circ} 46^{\circ} \mathrm{N}$ with an altitude of $1293.2 \mathrm{~m}$ above sea level. The local government area is bounded by Barkin- Ladi local government to the South, Riyom local government to the South West, Jos-East local government to the East and Bassa Local Government to the West (Figure. 1). The local Government has a population of 650,835 (National population Commission, 2006) with an average land area of $1,037 \mathrm{~km}^{2}$.

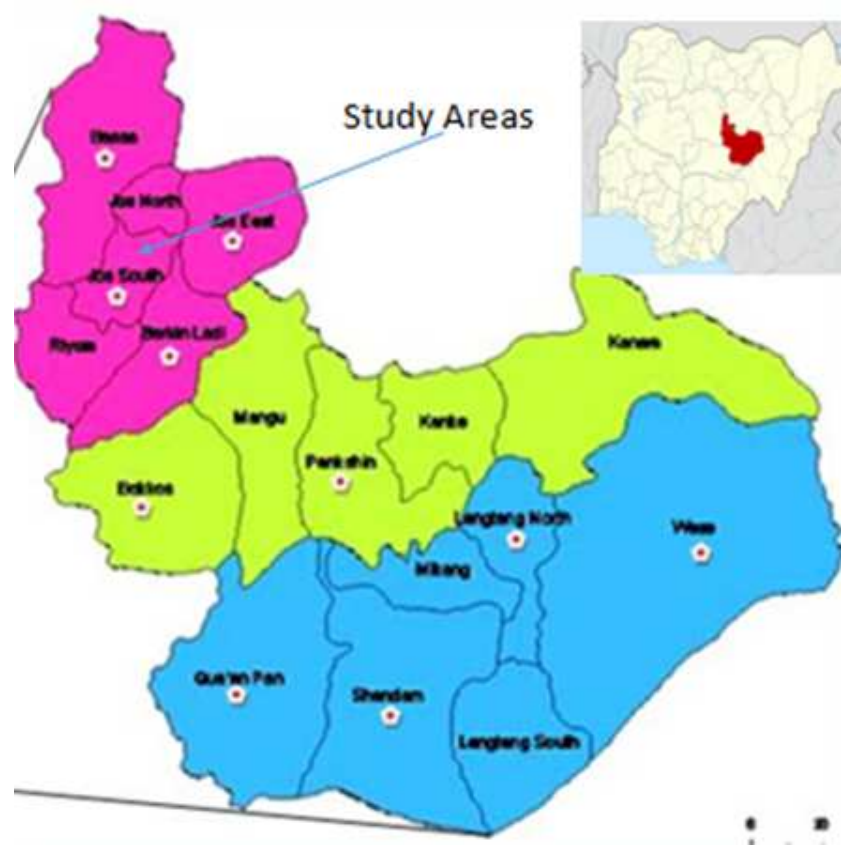

Figure 1. Location map of study areas

This paper makes use of two types of data. The first data is secondary sourced materials from past studies e.g. books and journals. The second data is from administering of questionnaire. Purposive sampling design was followed in the selection of 200 farmers. The study was conducted in four districts of Jos-South (Du, Vwang, Kuru and Gyel).One village was selected from each district using the simple random technique. Descriptive techniques of data were employed such as simple percentages to describe the knowledge of the respondents.

\section{Results and Discussion}

The number of respondents per location sampled reveals that the Kuru location has the highest with Vwang location recording the lowest number of respondents (Figure 2). The sex distribution ratio per each location was depicted in table 1. The results revealed that male and female constitute $47 \%$ and 54\% respectively. This implies that more females are into farming potato than males.

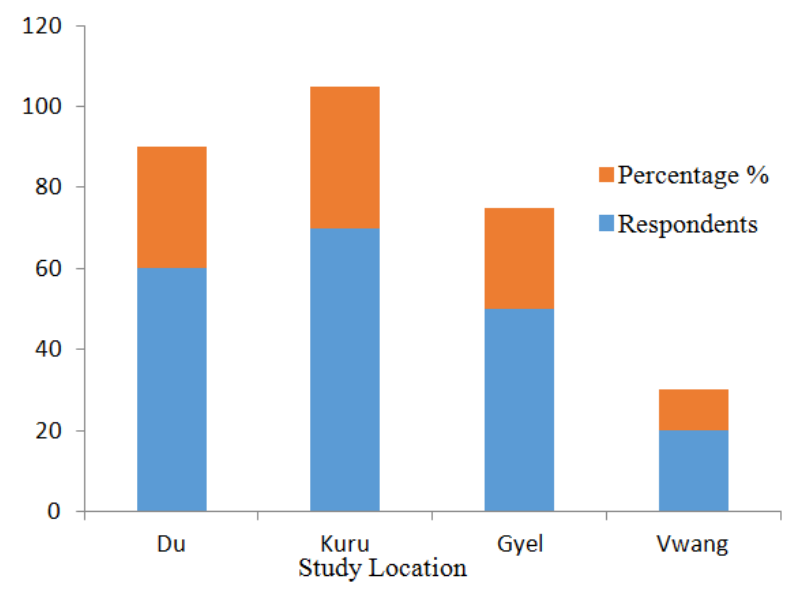

Figure 2. Number of respondents.

Table 1. Sex distribution of respondents.

\begin{tabular}{lllllllllll}
\hline Location & Du & \multicolumn{1}{l}{ Kuru } & \multicolumn{2}{c}{ Gyel } & \multicolumn{2}{c}{ Vwang } \\
\hline Sex & F & \% & F & \% & F & \% & F & \% & Total & \% \\
\hline No of Males & 29 & 48.30 & 30 & 42.9 & 22 & 44.0 & 12 & 60 & 93 & 46.5 \\
No of Females & 31 & 51.7 & 40 & 57.1 & 28 & 56.0 & 8 & 40 & 107 & 53.5 \\
Total & 60 & 100 & 70 & 100 & 50 & 100 & 20 & 100 & 200 & 100 \\
\hline
\end{tabular}

Key: F: Frequency Source: Field Survey, 2014

Table 2 shows both young and old people are involved in farming. The distribution shows that about $46 \%$ of the respondents were between 31-40 years of age. Respondents that were over 41 years of age constituted about $14 \%$.This imply that most of the respondent (about 86\%) was relatively young and physically active. This has a direct bearing on the availability of able-bodied manpower for agricultural production and also, age influence the ability to seek and obtain off-farm jobs and income which could increase.

Table 2. Age range of respondents.

\begin{tabular}{lllllllllll}
\hline Location & \multicolumn{1}{l}{ Du } & \multicolumn{1}{l}{ Kuru } & \multicolumn{2}{l}{ Gyel } & \multicolumn{2}{l}{ Vwang } \\
\hline Age group & F & \% & F & \% & F & \% & F & \% & Total & \% \\
\hline $20-30$ & 30 & 50 & 38 & 54.3 & & & & & 92 & 46 \\
$31-40$ & 23 & 38.3 & 25 & 35.7 & 22 & 44 & 10 & 50 & 80 & 40 \\
$41-50$ & 7 & 11.7 & 7 & 10 & 10 & 20 & 4 & 20 & 28 & 14 \\
Total & 60 & 100 & 70 & 100 & 50 & 100 & 20 & 100 & 200 & 100 \\
\hline
\end{tabular}

Key: F: Frequency Source: Field Survey, 2014

The literacy level of farmers which is an important factor that determines the ability of a farmer to understand policies and programmes relating to climate was employed in this research. The distribution of the respondents per each location is presented in Table 3. The table revealed that $8 \%$ of the respondents had no formal education, 33\% attained primary education, $43 \%$ had secondary education while $17 \%$ attained tertiary education. Thus, $92 \%$ of the respondents have some formal education. This study has revealed that 
literacy level is high amongst the respondents and this could have implications for agriculture production.

Table 3. Educational level of famers.

\begin{tabular}{|c|c|c|c|c|c|c|c|c|c|c|}
\hline \multirow{2}{*}{$\begin{array}{l}\text { Location } \\
\text { Educational level }\end{array}$} & \multicolumn{2}{|l|}{ Du } & \multicolumn{2}{|c|}{ Kuru } & \multicolumn{2}{|c|}{ Gyel } & \multicolumn{2}{|c|}{ Vwang } & \multirow[b]{2}{*}{ Total } & \multirow[b]{2}{*}{$\%$} \\
\hline & $\mathbf{F}$ & $\%$ & $\mathbf{F}$ & $\%$ & $\mathbf{F}$ & $\%$ & $\mathbf{F}$ & $\%$ & & \\
\hline Primary School & 18 & 30 & 17 & 24.3 & 20 & 40 & 10 & 50 & 65 & 32.5 \\
\hline Secondary School & 22 & 36.7 & 40 & 57.1 & 18 & 36 & 5 & 25 & 85 & 42.5 \\
\hline Tertiary Education & 18 & 30 & 10 & 14.3 & 2 & 4 & 4 & 20 & 34 & 17.0 \\
\hline No Formal Education & 2 & 3.3 & 3 & 4.3 & 10 & 20 & 1 & 5 & 16 & 8 \\
\hline Total & 60 & 100 & 70 & 100 & 50 & 100 & 20 & 100 & 200 & 100 \\
\hline
\end{tabular}

Key: F: Frequency Source: Field Survey, 2014

Information in table 4 indicates that $49 \%$ of the respondents have been farming potato for $11-20$ years. $30 \%$ of the respondents have been farming potato for 1-10 years while $22 \%$ have been farming Potato for 21-30 years. This implies that knowledge of the respondents on the effects of climate that affect the growth and yield of potato develop as they put more years in potato farming. They become more matured and conscious thereby gaining more experience on the understanding of the environment. This statement corroborates with the study of Boulding (1956) who suggested that over time, individuals developed mental impressions of the world through their everyday contacts with the environments, with these impressions knowledge acting as the basis for their behaviour.

Table 4. Years of farming experience by respondents.

\begin{tabular}{lllllllllll}
\hline Location & Du & \multicolumn{6}{l}{ Kuru } & \multicolumn{1}{l}{ Gyel } & \multicolumn{2}{l}{ Vwang } \\
\hline Year & F & \% & F & \% & F & \% & F & \% & Total & \% \\
\hline $1-10$ & 18 & 30 & 22 & 31.4 & 11 & 22 & 8 & 40 & 59 & 29.5 \\
$11-20$ & 30 & 50 & 28 & 40 & 30 & 60 & 9 & 45 & 97 & 48.5 \\
$21-30$ & 12 & 20 & 20 & 28.6 & 9 & 18 & 3 & 15 & 44 & 22.0 \\
Total & 60 & 100 & 70 & 100 & 50 & 100 & 20 & 100 & 200 & 100 \\
\hline
\end{tabular}

Key: F: Frequency Source: Field Survey, 2014

Table 5 reveals that $29 \%$ of the respondents said soil temperature affects the germination and growth of potato, $18 \%$ said air temperature affects the germination and growth of potato while $54 \%$ said rainfall affects the germination and growth of potato. This farmers' observation on climatic elements corroborated the findings of Wuyep et al., 2013 that precipitation effectiveness is important for good germination or sustained growth of potato which have effect on the final yield. It also confirmed the assertion made by Ifenkwe and Okonkwo (1983) that during the rainy season, time of planting depends on the onset of rain when rain becomes stable usually between the last week of April and first week of May.

Table 5. Respondents knowledge on climatic elements affecting germination of Irish potato.

\begin{tabular}{lllllllllll}
\hline Location & Du & \multicolumn{1}{c}{ Kuru } & \multicolumn{2}{c}{ Gyel } & \multicolumn{2}{c}{ Vwang } & \\
\hline Climatic elements & F & $\mathbf{\%}$ & F & $\mathbf{\%}$ & F & \% & F & \% & Total & \% \\
\hline Rainfall & 30 & 50 & 39 & 55.7 & 29 & 58 & 9 & 45 & 107 & 53.5 \\
Air temperature & 20 & 33.3 & 11 & 15.7 & 2 & 4 & 2 & 10 & 35 & 17.5 \\
Soil temperature & 10 & 16.7 & 20 & 28.6 & 19 & 38 & 9 & 45 & 58 & 29 \\
Total & 60 & 100 & 70 & 100 & 50 & 100 & 20 & 100 & 200 & 100 \\
\hline
\end{tabular}

Key: F: Frequency Source: Field Survey, 2014

Respondents' knowledge with regards to time of planting and harvesting of potato was analysed. It was revealed that $76 \%$ planted potato in April while $76 \%$ of the farmers also harvested potato in July Table 6 . This farmers' observation corroborated the findings of Ifenkwe and Okonkwo, 1983 that in Jos-South, potato is planted when rain becomes stable usually between the last week of April. Also, Ifenkwe, 1989 reported that yield declined with delay in date of planting probably as a result of premature killing of plants by lateblight disease.

Table 6. Respondents knowledge on the time of planting and harvesting of irish potato.

\begin{tabular}{|c|c|c|c|c|c|c|c|c|c|c|}
\hline \multirow[t]{2}{*}{ Location } & \multicolumn{2}{|c|}{ Du } & \multicolumn{2}{|c|}{ Kuru } & \multicolumn{2}{|c|}{ Gyel } & \multicolumn{2}{|c|}{ Vwang } & \multirow[b]{2}{*}{ Total } & \multirow[b]{2}{*}{$\%$} \\
\hline & $\mathbf{F}$ & $\%$ & $\mathbf{F}$ & $\%$ & $\mathbf{F}$ & $\%$ & $\mathbf{F}$ & $\%$ & & \\
\hline April planting period & 39 & 65 & 50 & 71.4 & 46 & 92 & 16 & 80 & 151 & 75.5 \\
\hline May planting period & 21 & 35 & 20 & 28.6 & 4 & 8 & 4 & 20 & 49 & 24.5 \\
\hline Total & 60 & 100 & 70 & 100 & 50 & 100 & 20 & 100 & 200 & 100 \\
\hline July harvesting period & 39 & 65 & 50 & 71.4 & 46 & 92 & 16 & 80 & 151 & 75.5 \\
\hline August harvesting period & 21 & 35 & 20 & 28.6 & 4 & 8 & 4 & 20 & 49 & 24.5 \\
\hline Total & 60 & 100 & 70 & 100 & 50 & 100 & 20 & 100 & 200 & 100 \\
\hline
\end{tabular}

Key: F: Frequency Source: Field Survey, 2014.

Table 7. Respondents knowledge on increase or decrease in temperature.

\begin{tabular}{|c|c|c|c|c|c|c|c|c|c|c|}
\hline \multirow{2}{*}{ Location } & \multicolumn{2}{|l|}{ Du } & \multicolumn{2}{|c|}{ Kuru } & \multicolumn{2}{|c|}{ Gyel } & \multicolumn{2}{|c|}{ Vwang } & \multirow[b]{2}{*}{ Total } & \multirow[b]{2}{*}{$\%$} \\
\hline & $\bar{F}$ & $\%$ & $\mathbf{F}$ & $\%$ & $\mathbf{F}$ & $\%$ & $\mathbf{F}$ & $\%$ & & \\
\hline Temperature increased & 40 & 66.7 & 62 & 88.6 & 30 & 60 & 19 & 95 & 151 & 75.5 \\
\hline Temperature decreased & 20 & 33.8 & 8 & 11.4 & 20 & 40 & 1 & 5 & 49 & 24.5 \\
\hline Total & 60 & 100 & 70 & 100 & 50 & 100 & 20 & 100 & 200 & 100 \\
\hline
\end{tabular}

Key: F: Frequency Source: Field Survey, 2014 
Table 7 shows that $76 \%$ noticed an increase in temperature while $24.5 \%$ of the respondents stated that temperature trend in the study area has decreased. The farmers' assessment agreed with the expert report Zemba et al., (2013) that temperature has increased in the Jos-Plateau and the yield of tuber is on the decline due to knobbiness and secondary growth at emergence/vegetative stage.

Table 8. Respondents knowledge on decreased and increased rainfall trend in the last five years.

\begin{tabular}{lllllllllll}
\hline \multirow{2}{*}{ Location } & \multicolumn{1}{c}{ Du } & \multicolumn{1}{c}{ Kuru } & \multicolumn{3}{c}{ Gyel } & \multicolumn{1}{c}{ Vwang } \\
\cline { 2 - 11 } & $\mathbf{F}$ & $\mathbf{\%}$ & $\mathbf{F}$ & $\mathbf{\%}$ & $\mathbf{F}$ & $\mathbf{\%}$ & $\mathbf{F}$ & $\mathbf{\%}$ & Total & $\mathbf{\%}$ \\
\hline Decrease in rainfall & 25 & 41.7 & 20 & 28.6 & 8 & 16 & 7 & 35 & 60 & 30 \\
Increase in rainfall & 35 & 58.3 & 50 & 71.4 & 42 & 84 & 13 & 65 & 140 & 70 \\
Total & 60 & 100 & 70 & 100 & 50 & 100 & 20 & 100 & 200 & 100 \\
\hline
\end{tabular}

Key: F: Frequency Source: Field Survey, 2014

The distribution of the respondents according to their assessment of rainfall trend in the area is represented in Table 8. Majority of the respondents $70 \%$ noticed an increase in rainfall while $30 \%$ opined that rainfall trend has been on a decrease. This implies that the more the rain at sprouting to emergence/vegetative and tuber set/initiation stage, the better the growth and yield of potato. This finding agrees with Zemba et al., (2013) that the total rainfall correlate significantly $(\mathrm{r}=0.470)$ with potato at $5 \%$ probability level.

Table 9 shows that $74 \%$ of the respondents indicated that rainfall trend affect the final yield of potato, $16 \%$ said minimum temperature affect the final yield of potato while $10 \%$ indicated that maximum temperature affect the final yield of potato. This implies that the higher the rainfall at tuber bulking stage, the lower the yield. This finding agrees with Wuyep et al., (2013) that high rainfall during tuber initiation of potato is not healthy to the crop as it causes poor aeration and subsequently poor development of tubers. Also, this finding corroborate with Zemba et al., (2013) that rainfall amount has negative correlation coefficient of -0.665 at $1 \%$ level of significance. This implies that the higher the amount of rainfall in July, the lower will be the yield. This is not surprising because the month of July coincides with tuber bulking/ripening stage.

Table 9. Respondent knowledge on variable affecting the final yield of irish potato.

\begin{tabular}{|c|c|c|c|c|c|c|c|c|c|c|}
\hline \multirow{2}{*}{$\begin{array}{l}\text { Location } \\
\text { Climatic elements }\end{array}$} & \multicolumn{2}{|c|}{ Du } & \multicolumn{2}{|c|}{ Kuru } & \multicolumn{2}{|c|}{ Gyel } & \multicolumn{2}{|c|}{ Vwang } & \multirow[b]{2}{*}{ Total } & \multirow[b]{2}{*}{$\%$} \\
\hline & $\mathbf{F}$ & $\%$ & $\mathbf{F}$ & $\%$ & $\mathbf{F}$ & $\%$ & $\mathbf{F}$ & $\%$ & & \\
\hline Minimum temperature & 4 & 6.7 & 25 & 35.7 & 1 & 2 & 2 & 10 & 32 & 16 \\
\hline Maximum temperature & 6 & 10 & 3 & 4.3 & 10 & 20 & 1 & 5 & 20 & 10 \\
\hline Rainfall trend & 50 & 83.3 & 42 & 60 & 39 & 78 & 17 & 85 & 148 & 74 \\
\hline Total & 60 & 100 & 70 & 100 & 50 & 100 & 20 & 100 & 200 & 100 \\
\hline
\end{tabular}

Key: F: Frequency Source: Field Survey, 2014

Table 10 reveals that $9 \%$ are of the opinion that maximum temperature causes lates-blight disease of potato, $14 \%$ opined that minimum temperature causes late-blight disease of potato while $76 \%$ said rainfall causes late-blight disease of potato. This implies that the more the rain during tuberization, the lower the yield of potato. Thus, the farmers assessment corroborate with the findings of expert Nwakocha (1987) that blight causes between $40-80 \%$ reductions in yield. The peak incidence is between July and August when the haulm of most susceptible varieties are destroyed by inciting pathogen phythopthora. This disease is accompanied by high relative humidity, dew and frequent rainfall (Hienfling, 1987).

Table 10. Respondent knowledge on the causes of late-blight disease of irish potato.

\begin{tabular}{llllllllllll}
\hline Location & Du & \multicolumn{1}{l}{ Kuru } & \multicolumn{7}{l}{ Gyel } & \multicolumn{2}{l}{ Vwang } \\
\hline Climatic elements & F & $\%$ & F & $\%$ & F & $\%$ & F & $\%$ & Total & $\%$ \\
\hline Rainfall trend & 50 & 83.3 & 50 & 71.4 & 37 & 74 & 18 & 90 & 155 & 77.5 \\
Maximum temperature & 4 & 6.7 & 10 & 14.3 & 3 & 6 & 1 & 5 & 18 & 9 \\
Minimum temperature & 6 & 10 & 10 & 14.3 & 10 & 20 & 1 & 5 & 27 & 13.5 \\
Total & 60 & 100 & 70 & 100 & 50 & 100 & 20 & 100 & 200 & 100 \\
\hline
\end{tabular}

Key: F: Frequency Source: Field Survey, 2014
Table 11 results shows that $35 \%$ of the respondents don't know how to eradicate this disease while $66 \%$ are of the opinion that early planting will halt the late-blight disease. This confirms the work of Ifenkwe (1989) that harvesting is carried out in early July to avoid destruction of tubers by inciting pathogen phythopthora.

Table 11. Respondents knowledge on overcoming late-blight disease of irish potato.

\begin{tabular}{lllllllllll}
\hline Location & Du & \multicolumn{1}{l}{ Kuru } & \multicolumn{2}{l}{ Gyel } & \multicolumn{2}{c}{ Vwang } \\
\hline & $\mathrm{F}$ & $\%$ & $\mathrm{~F}$ & $\%$ & $\mathrm{~F}$ & $\%$ & $\mathrm{~F}$ & $\%$ & Total & $\%$ \\
\hline Early planting & 43 & 71.7 & 40 & 57.1 & 37 & 74 & 11 & 55 & 131 & 65.5 \\
No knowledge & 17 & 28.3 & 30 & 42.9 & 13 & 26 & 9 & 45 & 69 & 34.5 \\
Total & 60 & 100 & 70 & 100 & 50 & 100 & 20 & 100 & 200 & 100 \\
\hline
\end{tabular}

Key: F: Frequency Source: Field Survey, 2014.

\section{Conclusion and Recommendation}

The conclusion drawn from the findings is that there is a good knowledge on the effect of climate on the growth and yield of potato among farmers in the study area. Also, the study depicts that farmers are experiencing the negative effect of climate in form of reduced crop yield. Based on these findings, the following recommendations are proffered 
1. The present planting period for potato is found suitable and should be maintained. This will help to maximize the positive effects of climate.

2. Information on climatic data should be collected all over the study area to provide information for long term planning.

3. Late-blight resistance varieties seed of potato should be developed in order to eradicate late-blight disease which reduces $40-80 \%$ yield of potato.

4. Seminars and workshop should be organized by the relevant authorities to enlighten the farmers more on effects of climate on growth and yield of potato

\section{References}

[1] Ahmed, S.A. (1980). Potato production in Bangladesh in proceeding of third international symposium on Potato production for South-Asia and pacific region held at Bandung, Indonesia.

[2] Boulding, J. (1956) in Adebayo A.A (1989). Man environment relations: The Geographers new points, pp15 unpublished lecture notes.

[3] Burton, W.G. (1989). The potato. Veenman and Zonen, Wageningen. Netherlands, 382.

[4] Hienfling, J.W. (1987). Late-blight of potato. Technical Bill. International potato center (IPC), 12.

[5] Ifenkwe, O.P \& Okonkwo,J.C. (1983). Determination of the most suitable time to plant Potato, taking into account the onset of rain. Annual report.of National Root Crop Research Institute, Umudike, Nigeria.

[6] Ifenkwe, O.P. (1989a). Comparison of flat and ridges for dry season planting of potato. Annual report of National Root Crop Research Institute, Umudike, Nigeria.
[7] International Indigenous People's Forum on Climate Change (IIPFCC, 2009). Policy paper on climate change. A policy paper finalized at the IIPFCC meeting in Bangkok, Thailand. September 26-27, 2009.

[8] Kowal, J.M \& Andrew, D.J. (1973). "Patterns of water availability and water requirement for grain sorghum production at Samaru, Nigeria. Tropical Agriculture (Trinidad), 50:89-100.

[9] Lopez, D.F, Boe A.A, Johnsen R.H \& Jansky,S.H. (1987). Genotype $\mathrm{X}$ environment interactions, correlations and coping ability of six traits in potato. American potato, 64:44.

[10] Maharjan, S.K, Sidjel E.R, Sthapit B.R \& Regmi, B.R. (2011). Tharu community's perception on climate change and their adaptative initiations to withstand its impacts in Western Terai of Nepal. International N.G.O, 6(2): 35-42.

[11] Natural Sciences (2012). Turning tables on change: Indigenous assessments of impacts and adaptation.http://www.unesco.org/new/en/natural sciences.12/07/2014

[12] Nwokocha, H.N. (1987). Weed interference studies in potato. Annual report, National Root crops Research Institute, Imudeke, 88-93.

[13] UNESCO (2010). The role of traditional and local knowledge on climate adaptation. A session at the $5^{\text {th }}$ Global conference on oceans, coasts and islands. Ensuring survival preserving life and improving governance. May 3-7, 2010 at UNESCO in Paris.

[14] Wuyep, S.Z, Zemba A.A \& Jahknwa C.J. (2013). Effects of precipitation effectiveness on the yield of potato (Solanum Tuberosum) in Jos-Plateau, Nigeria. International Journal of Research in Applied Natural and Social Science, 1, 5: 27-32.

[15] Zemba, A.A, Wuyep S.Z. Adebayo A.A \& Jahknwa, C.J (2013). Growth and yield response of potato (Solanum Tuberosum) to climate in Jos-South, Plateau State, Nigeria. Global Journal of Human Social Science, xiii, 1: 13-18. 